\title{
Participatory Mapping and Poetry Route for Determining Environmental Problems in Upper Citarum Living Lab
}

\author{
Dhayita Mahandani ${ }^{1}$, Sania Septiani Mulyawan ${ }^{1}$, Dwina Roosmini ${ }^{1}$, Loes Witteveen ${ }^{2}$, \\ Tjallie Botden-Scheltinga ${ }^{2}$, and Ira Dwi Mayangsari ${ }^{3}$ \\ \{dmahandani@gmail.com, saniasept@gmail.com,dwina@ftsl.itb.ac.id, loes.witteveen@hvhl.nl, \\ tjallie.botden@hvhl.nl,iradwi@telkomuniversity.ac.id\} \\ ${ }^{1}$ Institut Teknologi Bandung, Kota Bandung, Indonesia \\ ${ }^{2}$ Van Hall Larenstein University of Applied Science, Leeuwarden, Netherlands \\ ${ }^{3}$ Telkom Univeristy, Kota Bandung, Indonesia
}

\begin{abstract}
This essay explains about the Upper Citarum Living Lab project held by Van Hall Larenstein University of Applied Sciences, Institut Teknologi Bandung, and Telkom University in cooperation with local governmental organizations. With the aim to convey $21^{\text {st }}$ century skills, Living Lab facilitator training and community involvement is achieved by implementing innovative and creative approaches such as participatory mapping and poetry route to address environmental problems and discover a solution. This is a sustainable project with the area of focus is Ciwalengke and Sukahaji Village, Majalaya and Cipaku Village, Banjaran, West Java. This creative method of research and approach is relatively new to Indonesia and although it is complex due to the number of problems and collaborators needed, it should be taken into consideration when conducting community development programs.
\end{abstract}

Keywords: Living lab; Participatory mapping; Poetry route; $21^{\text {st }}$ century skills

\section{Introduction}

Upper Citarum Living Lab was formed as an interdisciplinary collaboration between Indonesian and Dutch partners with a joint interest for the environment which includes river restoration, sediment management, domestic waste management, agroforestry, and also community based approaches, social learning, communication and media design. Living lab is a research concept where stakeholders form a citizen-public-private partnership (C3P) to create, validate, and test new technologies, services, products, and systems in real-life contexts [9]. A living lab should include a 'quadruple helix' participation system, authentic learning environments that focus on a sustainable future, is able to stimulate reflexivity in learning and innovation for sustainability, and facilitates interaction, knowledge sharing and open system management [11]. Whilst embarking on (international) partnerships in Living Labs, it is realized that although the societal justification for new and urgent spaces of communication, participation and learning in times of sustainability issues and climate change adaptation is widely recognized; formal education curricula are not yet aligned with the training of 
professionals involved. Skills such as critical thinking, reflexivity, media literacies, creative methodologies, horizontal communication processes, and facilitation of living lab processes are not yet found in the curricula of the life sciences. Further exploring such (trainable) skills and capabilities are increasingly referred to as 21 st century skills. These 21 st century skills are grouped in 5 dimensions, they are thinking dimension, communication dimension, selfmanagement dimension, participating and contributing dimension, and ethics and social impact dimension [1].

In November 2018 three knowledge institutes, namely Van Hall Larenstein University of Applied Science, Institut Teknologi Bandung, and Telkom University, embarked in the context of the Living Lab Upper Citarum on a project to explore 21st century skills through non-formal training for project partners who will act as facilitator trainees during Living Lab Upper Citarum community based activities. The research strategy of this recent Upper Citarum Living Lab activity was to create a space to explore skills and capabilities that are supportive and trainable to increase the performance of a Living Lab. The project involved two communities that live along the river, specifically Ciwalengke and Sukahaji Village in Majalaya and facilitators of living lab such as the Environmental Protections Agencies (EPA), Housing, Planning and Housing Agencies, Knowledge Institutes and a local NGO. The resulting output was in a later stage transferred to Cipaku Village in Banjaran, a more upstream community. In Banjaran the trainees and Living Lab facilitators had to facilitate the use of the creative strategies for inhabitants of Banjaran with the support of inhabitants of Ciwalengke and Sukahaji Village. The results and analysis of implications for both Living Lab facilitation and follow up activities in the Living Lab were later shared during a minisymposium in Bandung.

The creative strategies practiced within this living lab project are participatory mapping and poetry route. Both methods implement a community based approach. Participatory mapping is where communities work together to produce a map of their environment. This approach to map-making assumes expert familiarity and knowledge of the local community. Maps are essential for planners, policy-makers, and residents. To make participatory maps functional for uses outside the community, it is needed that the community, as map producers, cooperate and agree on the function and interpretations of colors, symbols, and other signs used in the map. Participatory mapping also allows the community to reflect on the current situation and envision how to better their living space along with planners and policy-makers. The second method explored in the project is a poetry route which is a method to articulate the community's opinions and imaginaries towards a certain issue through community art. The end result of a poetry route is a combination of poems and paintings created by the community themselves that tells a story of their perception of the environment and their surroundings. The elaboration of the art works in a series of printed banners constitutes a poetry route which can circulate and thereby can be shared with other communities and in diverse platforms with the ambition to raise awareness, to establish conversations and to create motivation on the issue at stake.

\section{The Project Activities}




\subsection{Facilitator workshop and training}

On Tuesday, November 13th 2018 the first workshop and training session for future facilitators was held at the Civil Engineering Alumni Hall, Institut Teknologi Bandung from 9 am to $4 \mathrm{pm}$. The aim of the workshop was to introduce the living lab concept and methods to future facilitators and living lab participants. Many course participants from both governmental and non-governmental organizations attended this workshop such as West Java Environmental Agency, Bandung City Environmental Agency, Housing and Settlement Service Office, BBWS Citarum, and also academic institutions namely Institut Teknologi Nasional, Universitas Padjadjaran, Universitas Pasundan, and Universitas Kebangsaan. A total of 28 participants had joined this workshop.

The workshop started with opening remarks from the Dean of Faculty of Civil and Environmental Engineering, Prof. Ir. Ade Sjafruddin, M.Sc., Ph.D., followed by a brief introduction by each project partner. First, an introduction of living labs given by Dr.Ir. Dwina Roosmini, MS as one of the lead researchers from Institut Teknologi Bandung (ITB). Participatory mapping and poetry route method was then explained by Loes Witteveen, Ph.D., as the lead researcher from Van Hall Larenstein University of Applied Sciences (VHL). Next, Ira Dwi Mayangsari from Telkom University spoke about environmental communication while Pampang Parikesit, Ph.D of Universitas Padjadjaran shared about agroforestry in Indonesia. For the next session, exercise of participatory mapping and poetry route, Loes Witteveen caught everyone's attention when they were enjoying their lunch break. She explained that she did so because when working with communities, people will be doing their daily activities and we have to know how to gain people's attention. Especially when you are an outsider, you have to present yourself in a way to attract the community to yourself and the program you are proposing. To begin the exercise, the participants grouped in pairs and were given a sheet of paper and pencil. The instructions were to draw a map of the hall where the workshop was held. Afterwards all of the participants gathered around a large table and lined up their drawings. Each and every drawing had similarities like rectangles to illustrate tables and chairs where as some were more detailed than others. For example, only one group had drawn the structural pillars of the hall which, not surprisingly, was drawn by a group with engineer members. By comparing the differences of the maps, a complete map could be created and every participant shared the same frame about the map legend.

To begin the poetry route exercise, the participants had to spread out across the room so that they would not be distracted by fellow participants. Each participant received two paint brushes, a sponge, 6 colors of paint, and sheets of paper. While soft, relaxing music played in the background. The first painting was to draw a line using one color and one brush. The participants were invited to select a different brush and a different color of paint for making round shapes. The next painting was to use another brush and color to create whatever the participant wanted. For the final painting, the directions were to illustrate a river with any technique. Finally all participants wrote four poetic sentences about a river. After collecting every poem and painting, we had a short reading of the poems and matched each one with a painting by voting.

The workshop was very fascinating and innovative because it is a new and uncommon method to approach communities. Art and creative approach results in a fun and relaxed environment for both the facilitator and participant. By having this experience, the living lab facilitators were enabled to anticipate the events to follow at community level.

2.2. Participatory Mapping 
Participatory mapping is one of the series of activities that took place at Ciwalengke and Sukahaji Village. On the first day of gathering, November 14th 2018, Loes Witteveen, Dwina Roosmini, Ira Dwi Mayangsari and Tjallie Botden introduced themselves and other facilitators. They also described the aims and goals of the project in general to the community of Sukahaji and Ciwalengke. Introduction was conducted to clarify the communities understanding about the purpose of the series of activity that will be held for the next few days. The presence of Loes Witteven and Tjallie Botden made the communities seem bashful and nervous. This was shown through the behavior of the communities; they only smiled and nodded instead of answering the question translated by the facilitator. As the time went by and the activities started, the ambience became warmer because of the interaction between the facilitator and the communities. The leader of the community village (Rukun Warga) and the community participants were divided into two groups, based on their living region (Sukahaji and Ciwalengke Village). All community participants then all started drawing a map of their house and surrounding area of their house individually and were asked to make a legend of their own map. After that, all participants drew the members of their family on the small papers and name each household member.

Next, both communities gathered together to compile the community map according to the actual condition. While arranging the maps, facilitators asked the participants to clarify the time setting and it was agreed that it was in the morning. Therefor children were at school, the men were at work, and the women were either at home or working. This setting motivated community participants to be explicit about the whereabouts of their family members at that specific time which resulted in the inclusion of more detailed socio economic activities in the map such as the factories and the market. The facilitators supported this process by raising questions and continuously handing out papers to the participants to illustrate. As the facilitator, we do not have to be involved a lot in the discussion. Instead, facilitators only need to become a good listener about their issues.

It was interesting to see a difference in detail of the maps between Sukahaji and Ciwalengke. The result of Sukahaji was more detailed compared to Ciwalengke. Based on our observation during map arrangement and discussion, the communities in Sukahaji were more active and had more fruitful discussions. In Ciwalengke community, the facilitators had to trigger them more often in order to obtain a result.

Even though the villages are close together, the condition of the village have few differences. For example, Sukahaji has free clean water from the industrial fund (CSR project) while Ciwalengke does not. Sukahaji experiences floods more often than Ciwalengke but has a better waste management system. To discover those differences, we asked Sukahaji Communities how they are able to operate a good waste management system and have clean water. The result is the appearance of the hamlet leader (Ketua RW). The leader in Sukahaji provided community training for utilizing recycle waste, better waste management, and he often attends activities that concern community development.

The last stage was completing the map with public facilities and infrastructures such as bridges, gardens, and streets through discussion within community participant themselves. Positioning the rivers, sanitation, water collection ponds, laundry washing places, bio pore holes, ground water well, sewerage, MCK (mandi cuci kakus; lavatory), and other water and sanitation facility surrounding their living area resulted a more complex task. Indicating the flow directions of river, waste and other waters turned out to be a challenge. Facilitators supported this process by asking various questions about access to drinking water, the flow of wastewater, and how the community manages their solid waste. These discussions, also supported the community to classify the area with high or potential risk in environmental 
issues such as flood and drought. Particular issues where indicated by putting sticky notes in different colors on the map.

Facilitators support the process of participatory map by being continuously interactive with the community. The final envisioned map has to be clear in signing or coding. The participatory mapping should be agreed and recognized by each participant. This map was then documented and collected to be reproduced and used by other communities which link to the river Citarum. These final maps will be printed on canvas for durability. Materials and tools for the participatory mapping production activity used include paper, soft pencils, erasers, sharpeners, color markers, sticky notes and scissors.

At the end of the activity, the facilitators expressed gratitude for the cooperation with the communities and stakeholders. After the community went home, the stakeholders and facilitators had a further discussion and evaluation about the event, exchanging their experiences and views.

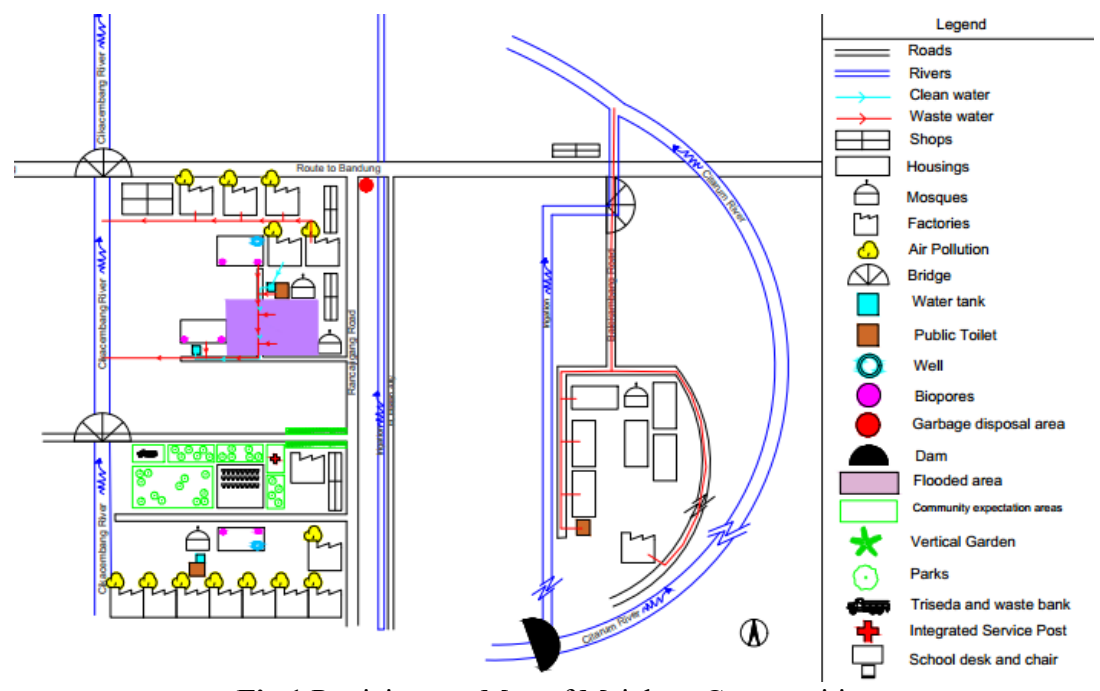

Fig 1 Participatory Map of Majalaya Communities

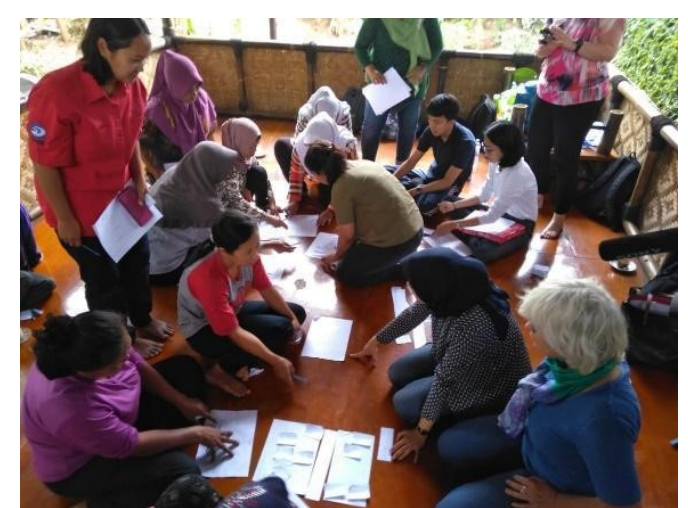

Fig 2 Participatory Mapping with Ciwalengke Community (Source: IKOM Channel)

\subsection{Poetry Route}


The Poetry route activity took place on November 15 th 2018 . The ambience was warmer than the first day and the community was excited to start the activities. There were more participants from Sukahaji and Ciwalengke Village who attended this workshop. After giving a general introduction about the activity, each participant was given the tools and materials for painting on paper. The workshop started with rounds of so-called painting exercises which were collected and hanged in the 'Ciwalengke Art Museum' to create a conducive, creative atmosphere. Living Lab facilitators (trainees) apprehended that they had to respect all the painting and take care the painting wholeheartedly. The main facilitator observed particular and outstanding details of each painting and shared this with the communities. We could see the differences emotions being portrayed in each painting. Some showed happiness with bright and vibrant colors while others were sad or mad which was shown through darker tones. While the community was painting, instrumental music was played in the background to stimulate relaxation and creativity. In a second round of painting, the participants were invited to paint their views towards river issues. Participants really enjoyed the painting session. For some of the participants, this was their first time to drawing with the brush and the paint so they felt satisfied and thrilled. Based on observations, the communities were enthusiastic and could express their feelings through their painting. Due to this, the results were authentic and genuine.

After a quick lunch break, the community was asked to express their feelings about Citarum River through poetry. In only eight sentences or more, the community wrote how they view the current Citarum condition and what are their hopes and wishes for Citarum. Once the poems were finished, they were read aloud and the community would decide for a painting that community had already made, which was visible in the "Ciwalengke Art Museum'. Materials and tools for poetry route were paper, acrylic paints, brushes, water, sponges, tissues, pencils and erasers. It is also important to mention that the participants were welcome to collect 'garden brushes' and use leaves, sticks and other things found in the garden to use as other options for painting.

All poems and paintings were collected for post-production: after text editing and translation into multiple languages, they would be printed on canvas banners with the selected painting as the background. This combined result was then named as "The Voice of Citarum."

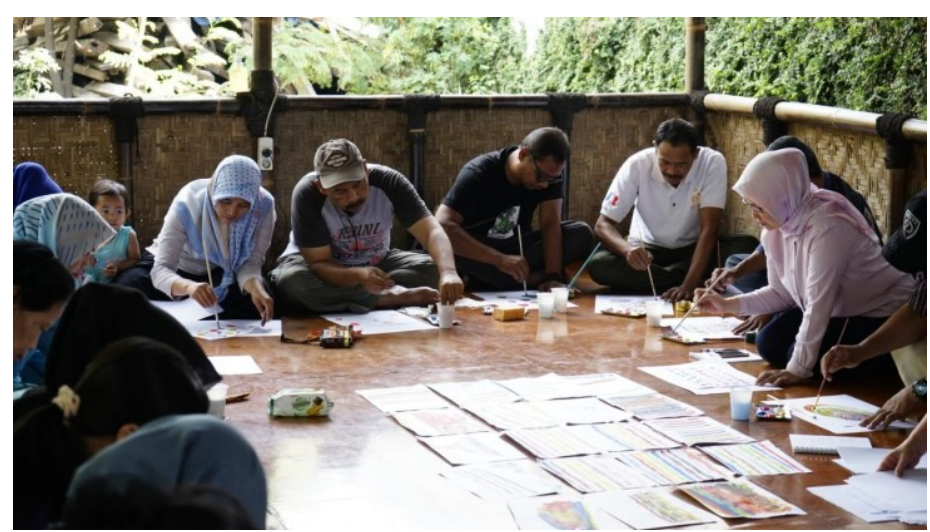

Fig 3 Community members painting (Source: IKOM Channel) 


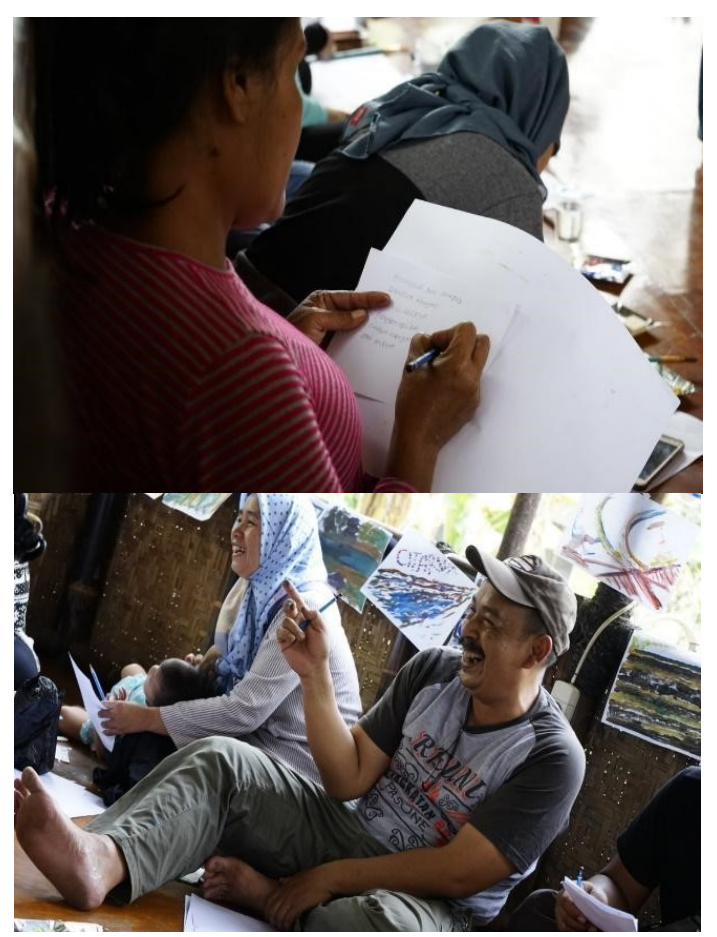

Fig 4 Community members creating the poetry route (Source: IKOM Channel)

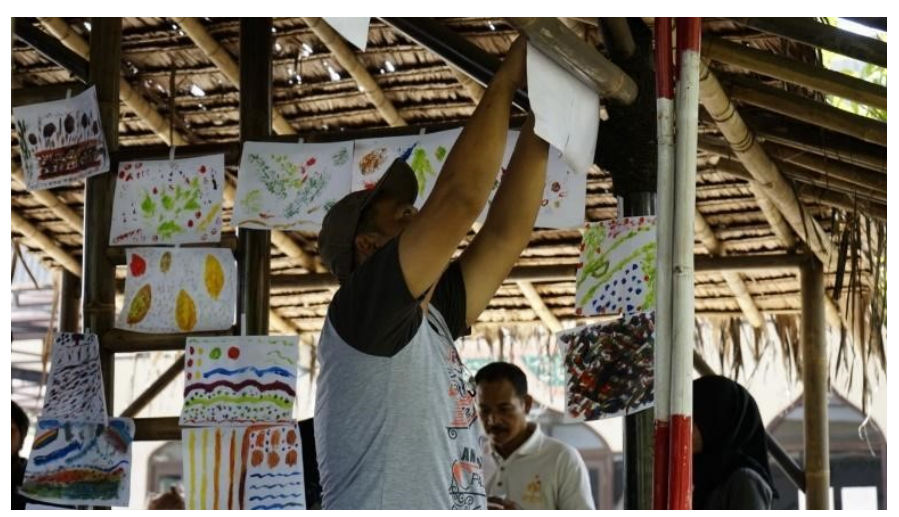

Fig 5 Matching paintings with poems as a community decision (Source: IKOM Channel)

\subsection{Informed Consent}

The fieldwork of the project in Ciwalengke and Sukahaji Village in Majalaya, and Cipaku Village, Banjaran has been organized in cooperation with EPA West Java Province, EPA Bandung District, and Environmental NGO Elingan and has been announced in advance to the participating community members who participated out of their own free will. After all the participatory mapping and the community art activities the objectives and follow up activities were again presented to the community members in an open discussion. The discussion first focused on the activities to bring the outcomes from the community activities to a transferable printed product. Secondly the objective and procedures for the use was (again) presented and 
discussed. Representatives of the Sukahaji and Ciwalengke Village community were invited to present their maps in Banjaran Village in the presence of the trainees in the course on Living Lab facilitation. Each representative for both community will exchange the meaning of the maps. The maps that needs to be linked with the river and both communities for further discussion. The poetry route that produced by Ciwalengke and Sukahaji Village community members will be exhibited on a first occasion in Banjaran to initiate conversations about the river. To adhere to ethical standards of academic research and create access to the procedures followed this informed consent procedure has been documented on video.

\subsection{Utilization of Participatory Map and Poetry Route}

On Monday, November 19th 2018 the facilitators, project partners, and representative of Ciwalengke and Sukahaji Village traveled to Cipaku Village, Banjaran to share the results from the previous sessions. This meeting was also attended by the local government representatives and environmental awareness communities.

The participants were divided into four groups consisting of facilitators and representatives from each village. The map of Ciwalengke and Sukahaji was printed on A3 paper and explained by the community. Cipaku community listened and exchanged questions and comparisons about their condition in Banjaran. From this session, both communities gained a wider perspective on the diversity of life along Citarum River. It was interesting to watch communities share the same positivity towards a clean and better environment.

The next activity was sharing the poetry route with Cipaku Village. Banners of the Voice of Citarum were displayed in the front of the room. The authors of the poems were asked to come front and read their poems aloud to the other participants. The creators of the poems and paintings were very pleased as they received applause from the other participants but the message and meaning of the poem was not absorbed by the participants. This may be because of the way the poems were read. If the ambience was solemn, the participants could have had a better understanding of the poems.

After sharing about the current condition in all communities and the condition of Citarum River, each community was asked to discuss problem priorities and solutions for each problem. The two main problems issued in all groups were solid waste management and access to clean water. For solid waste management, most of the communities agreed that having a waste/recycling bank and a scheduled waste collection by the authorities could help solve the problem. Currently waste is being disposed of in piles along the street and burned. The communities also share the same vision about getting clean water from deep wells.

While the communities were presenting their group outcomes, the local government and industry representatives took note and shared their perspectives. This established the start to a better connection and respect between communities and stakeholders because of transparency of communication. Both the communities and stakeholders engaged in the discussion and expressed that to create a clean and healthy environment they need to work together. 


\section{Conclusion}

Creative community approaches have strategic potential in upper Citarum Living Lab. The creative approaches participatory mapping and poetry route, have become a pioneer project which is promising for future community development programs. The new method for initial data collecting is experienced as pleasant, inclusive and accessible for community members. Although, implementing this method must require training for facilitators from governmental and or non-governmental organizations because communicating with communities takes time and practice in order to be able to achieve optimum results. The impact of using the outcomes resulting from these methods can improve and accelerate community development because the community quickly illustrates problems and is able to find solutions while directly discussing the possibilities with the authorities. This creates a transparent, horizontal communication system. Recommendation for participatory mapping and poetry route in the future are:

1. All stakeholders involved must share a similar vision and commitment to pursue the Upper Citarum Living Lab because good collaboration is a key factor of a successful living lab.

2. Ice breaking is important so the communities are enabled to participate in the activity. This is a responsibility of the living lab facilitator.

3. In the end of each session, the living lab facilitator should recall the activities and discuss with the community about the meaning/goals/aims of the activities. This should be done to clear any confusions or vagueness the community has.

4. The living lab facilitator should be careful when guiding the community to come up with conclusions and solutions. Facilitation should support communities to determine and decide their own solutions even though it might not be realistically accomplished.

5. The facilitator may trigger communities in case they do not have any idea for what their problem is by asking them some questions related on the topic.

6. The attendance of the Ketua RT (neighborhood head) or Ketua $R W$ (hamlet head) is also important because they are more familiar with the current condition and are able to communicate it to the community and higher stakeholders.

7. The plenary session will be facilitated to discuss the current situation and what should or could happen to change the situation. Also, discussing the role and responsibility of each stakeholder in order to achieving the envisioned situation.

\section{Acknowledgment}

This paper was supported by SiA Nationaal Regieorgaan Praktijkgericht Onderzoek, Netherland within a project of Creative Strategies and Public Participation as Convincing Strategies in The (Re) Configuration of Living Lab ; Exploring 21st Century Skills in Complex Multi Stakeholder Situation: the Living Lab Upper Citarum, Java, Indonesia, collaboration between Van Hall Larenstein University of Applied Science, Institut Teknologi Bandung, and Telkom University 


\section{References}

[1] Ananiadou, Katerina \& Magdalean Claro. [2009]. 21st Century Skills and Competences for New Millennium Learners in OECD Countries in http://www.oecdilibrary.org/docserver/download/218525261154.pdf?expires=1521129270\&id=id\&accname=gue st\&checksum=2351556A45B6 A50ADFC71A267C734F27 globaldigitalcitizen.org/21stcentury-skills-every-student-needs [accessed 27 November 2018]

[2] Gelmon, Sherril B. [2003, April]. The Evaluation Perspective In Barbara A. Holland, Community-University Partnerships: What Do We Know? Symposium conducted at the meeting of the Community-Campus Partnerships for Health and HUD's Office of University Partnerships, San Diego, CA

[3] Green, Lawrence W. [2003, April]. The Community-Based Participatory Research Perspective In Barbara A. Holland, Community-University Partnerships: What Do We Know?. Symposium conducted at the meeting of the Community-Campus Partnerships for Health and HUD's Office of University Partnerships, San Diego, CA

[4] Greene-Moton, Ella. [2003, April]. Community Perspectives on Community-University Partnerships In Barbara A. Holland, Community-University Partnerships: What Do We Know? Symposium conducted at the meeting of the Community-Campus Partnerships for Health and HUD's Office of University Partnerships, San Diego, CA

[5] Holland, Barbara A. [2003, April]. Community- University Partnerships: Translating Evidence into Action In Barbara A. Holland, Community-University Partnerships: What Do We Know? Symposium conducted at the meeting of the Community-Campus Partnerships for Health and HUD's Office of University Partnerships, San Diego, CA

[6] Johari, Aiza, Affidah Morni, Dayang Faridah Abang Bohari and Siti Humaizah Sahari.[2013].Conflicting Environment at Workplace: UiTM Sarawak's Lecturers. ProcediaSocial and Behavioral Sciences 101 (2013) 554-563

[7] Kotas, Maria. [2015]. Identifying of Critical Success Factors of Social Services Organizations in the Public Sector. The Business and Management Review, Vol. 6 (4). University of Economics, Katowice, Poland

[8] Stanton, Timothy K. [2003, April]. The Service-Learning Perspective In Barbara A. Holland, Community-University Partnerships: What Do We Know? Symposium conducted at the meeting of the Community-Campus Partnerships for Health and HUD's Office of University Partnerships, San Diego, CA

[9] Westerlund, M., \& Leminen, S. [2011]. Managing the challenges of becoming an open innovation company: Experiences from Living Labs. Technology Innovation Management Review, 19-25.

[10] Weyers, Michael L., Andriette M. van den Berg. [2006]. The Success Factors in Community Work Services: A Critical Incident Study. International Social Work 49(2): 177-187

[11] Witteveen, L., Eweg, R., Smits, S., Voskamp-Harkema, W., [2016]. Design principles for Living Lab's aiming at sustainable development. The role of higher education in Living Lab's. Paper presented at Competence 2016. Wageningen.

[12] Witteveen, Loes and Jacomien den Boer. [2018]. "River Flows - An Artistic Approach towards Community Resilience, Participation and Social Learning in Natural Resources Management." Chapter in nico Carpenties (ed.2018). Republika! Experiments in the performance of particiaption and democracy. Limassol: Neme, in press.

[13] http://conference.ntu.edu.sg/asaihl/Documents/PPTs/Parallel\%20Session\%20PPT/3 1_4\%20Mu chlas\%20Samani.pdf [accessed 27 November 2018] 